\title{
Peptides derived from Plasmodium falciparum leucine-rich repeat I bind to serine/threonine phosphatase type I and inhibit parasite growth in vitro [Corrigendum]
}

\author{
Pierrot C, Zhang X, Zhangi G, Fréville A, Rebollo A, Khalife J.
}

Drug Des Devel Ther. 2018;12:85-88.

On page 1, the author's name was incorrectly listed as

Gigliola Zhangi. Their correct name is Gigliola Zanghi.

Drug Design, Development and Therapy is an international, peerreviewed open-access journal that spans the spectrum of drug design and development through to clinical applications. Clinical outcomes, patient safety, and programs for the development and effective, safe, and sustained use of medicines are the features of the journal, which has also been accepted for indexing on PubMed Central. The manuscript management system is completely online and includes a very quick and fair peer-review system, which is all easy to use. Visit http://www.dovepress.com/testimonials.php to read real quotes from published authors. 